\begin{tabular}{|c|c|c|}
\hline & $\begin{array}{c}\text { International Journal of Current Research in } \\
\text { Biosciences and Plant Biology } \\
\text { BXCELLENT } \\
\text { PUBLISHERS }\end{array}$ \\
Volume $4 \bullet$ Number 8 (August-2017) $・$ ISSN: 2349-8080 (Online) \\
Journal homepage: www.ijcrbp.com
\end{tabular}

\title{
Evaluation of Peroxidase Activity in Selected Vegetables from Hyderabad, Telangana, India
}

\author{
Pradeep Kumar Jha, Bandaru. V.S.R.K.P. Ganesh Sandeep, K. Raju and M. K. Sukumaran*
}

Department of Biochemistry, Bhavan's Vivekananda College, Secunderabad-500 094, Telangana, India

*Corresponding author.

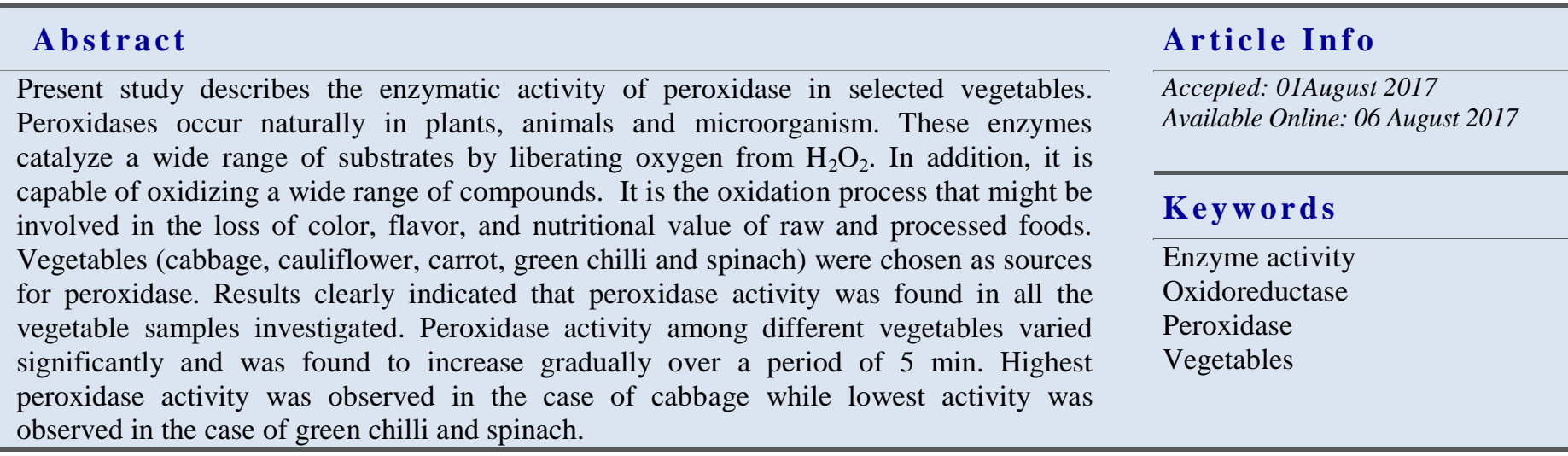

\section{Introduction}

Peroxidases (E.C.1.11.1.7), are distributed in plants like, radish, soybean (Ambreen et al., 2000), tomato (Zia et al., 2001), potato, turnip, carrot, wheat, pear, apricot, banana, dates (Reed, 1975), strawberry (Jen et al., 1980) and horseradish (Rehman et al., 1999); animals (leukocyte- Agner, 1943), spleen, lungs, mammary and thyroid glands, bone marrow and intestine (Harris and Loew, 1996) and microorganisms (Streptococcus faecalis - Reed, 1975). It is also reported in fruits like oranges (Clemente, 2002), peach (Neves, 2002), pears (Regalado et al., 2004) and apples (Singh et al., 2010).

It is an oxidoreductase, which catalyzes a redox reaction between $\mathrm{H}_{2} \mathrm{O}_{2}$ as an electron acceptor and many kinds of substrates by means of oxygen liberation from $\mathrm{H}_{2} \mathrm{O}_{2}$ (Brill, 1996).

$$
2 \mathrm{H}_{2} \mathrm{O}_{2} \stackrel{\text { Peroxidase }}{\longrightarrow} 2 \mathrm{H}_{2} \mathrm{O}+\mathrm{O}_{2}
$$

Peroxidases of plant origin are capable of oxidizing a wide range of compounds (e.g., guaiacol, pyrogallol, chlorogenic acid, catechin, and catechol (Onsa et al., 2004). This oxidation process may be responsible for losses in color, flavor, and nutritional value of raw and processed foods (Robinson, 1987; Nebesky et al., 1950; Bruemmer et al., 1976; Kampis et al., 1984). Peroxidases from plants exist as isoenzymes and its number may vary from one vegetable source to another. In addition they also differ in terms of thermal stability, optimum $\mathrm{pH}$, substrate specificity, amino acid 
composition and their physiological roles in the plant tissues.

Because of its heat stability (it is used to evaluate the heat processing of vegetables (Adams, 1997). Peroxidase finds its application in health sciences as a diagnostic tool (Kwak et al., 1995). In addition, it is also used in the preparation of enzyme conjugated antibodies which are widely used in ELISA and other sensitive analytical techniques (Barnes et al., 1993). It occupies a prominent place in the fields of Biotechnology and associated research areas (such as, Enzymology, Biochemistry, Medicine, Genetics, Physiology, Histoand Cytochemistry) (Azevedo et al., 2003). Other areas in which peroxides are used includes, chemical synthesis, medicine, analysis of food, chemicals, clinical and environmental samples (Agostini et al., 2002). In recent years it is used in the processes like detoxification and removal of variety of organic pollutants, e.g. aromatic amines, phenols, dyes, etc., from contaminated waste water (Duran and Esposito, 2000; Shaffiqu et al., 2002; Bhunia et al., 2001; Akhtar et al., 2005).

Keeping in view the importance of peroxidase the present study was aimed to evaluate and compare the levels of peroxidase activity in selected vegetables from the city of Hyderabad, Telangana.

\section{Materials and methods}

\section{Plant material collection}

Fresh vegetables (cabbage, cauliflower, carrot, green chilli and spinach) were purchased from local market in Hyderabad city. Before the extraction procedure, all the samples were thoroughly cleaned with $0.2 \mathrm{M}$ Potassium phosphate buffer $\mathrm{pH} 7.0$ to remove any adhering contaminants if present. Peroxidase activity in the vegetable samples was determined on the same day of purchase.

\section{Preparation of extract}

Sample (10 g) was homogenized in a blender using 2 $\mathrm{mL}$ of $0.2 \mathrm{M}$ Potassium phosphate buffer $\mathrm{pH}$ 7.0. The extract was then passed through cheese cloth. The filtrate was centrifuged at $10000 \mathrm{~g}$ for $10 \mathrm{~min}$ and the clear supernatant was labeled as crude extract. The extract was subjected to $65{ }^{\circ} \mathrm{C}$ for three min to inactivate any catalase activity present in extract (Rehman et al., 1999). After examining different volumes (10-100 $\mu \mathrm{L})$ of the crude enzyme for peroxidase activity assay, $20 \mu \mathrm{L}$ of the crude enzyme was finally selected to examine the peroxidase activity assay. Assay was carried out at room temperature. All the vegetables were similarly treated.

\section{Assay of peroxidase (POX) activity}

Assay of peroxidase was carried out according to the method of Sarika et al. (2015). Enzyme activity was determined in triplicates and results are represented as Mean \pm SD. The substrate used was hydrogen peroxide $\left(\mathrm{H}_{2} \mathrm{O}_{2}\right) /$ phenol/4-aminoantipyrine solution (Porstmann, 1981). $\mathrm{H}_{2} \mathrm{O}_{2}$ rapidly reacts with 4 -aminoantipyrine-phenol solution in the presence of peroxide to produce a quinoneimine chromogen (http://www.amanoenzyme.co.jp) which shows intense pink colour with a maximum absorbance at $510 \mathrm{~nm}$. Aminoantipyrine and phenol were used at concentrations of $0.0025 \mathrm{M}$ and $0.17 \mathrm{M}$ respectively. In this method the amount of quinoneimine (Fig. 1) formed was influenced by the amount of peroxidase present. Data is represented as mean \pm SD for each of the vegetable sample investigated.

$$
2 \mathrm{H}_{2} \mathrm{O}_{2}+4 \text {-aminoantipyrine }+ \text { phenol } \stackrel{\text { Peroxidase }}{\longrightarrow} \text { quinoneimine dye }+4 \mathrm{H}_{2} \mathrm{O}
$$

Chemical structure of the quinone-imine dye produced in the reaction is presented in Fig. 1 (Trinder and Webster, 1984).

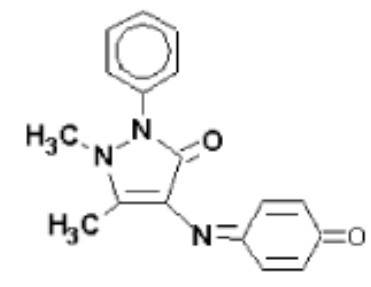

Fig. 1: Quinone-imine product.

Table 1. Assay of peroxidase activity.

\begin{tabular}{|c|c|c|c|c|c|c|c|}
\hline \multirow{2}{*}{$\begin{array}{l}\text { S. } \\
\text { No. }\end{array}$} & \multirow{2}{*}{$\begin{array}{l}\text { Vol. of } \\
\text { Enzyme } \\
(\mu \mathrm{L})\end{array}$} & \multirow{2}{*}{$\begin{array}{l}\text { Vol. of } \mathrm{PO}_{4} \text {. } \\
\text { buffer }(\mu \mathrm{L})\end{array}$} & \multirow{2}{*}{$\begin{array}{l}\text { Volume of } 4 \text { - amino } \\
\text { anti pyrine }-\mathrm{H}_{2} \mathrm{O}_{2} \\
(\mathrm{~mL})\end{array}$} & \multicolumn{4}{|c|}{ Absorbance at $510 \mathrm{~nm}$} \\
\hline & & & & $1^{\prime} \quad 2$ & 3 , & $4{ }^{\prime}$ & 5 , \\
\hline 1 & 20 & 80 & 2.9 & & & & \\
\hline
\end{tabular}

\section{Results and discussion}

Vegetables (cabbage, cauliflower, carrot, green chilli and spinach) were chosen as sources for peroxidase. During the peroxidase enzyme assay change in absorbance value was recorded at a time interval of 1 min over a total period of $5 \mathrm{~min}$. The change in 
absorbance values at $510 \mathrm{~nm}$ versus time is summarized in Table 2 and depicted in Fig. 2. Results presented in Table 2 and Fig. 2 clearly indicates that peroxidase activity was found in all the samples of vegetables investigated. The presence of peroxidase activity in different fruits and vegetables has been observed by many investigators (Gorin and Hemidema, 1976; Haard, 1977; Müftügil, 1985; Meclellon and Robinson, 1987; Rhotan and Nicolas, 1989; Miesle et al., 1991; Neves, 2002; Llano et al., 2003). Peroxidase activity among the different vegetables varied significantly and enzyme activity was found to increase gradually over a period of 5 min (Table 2). Highest peroxidase activity was observed in the case of cabbage while lowest activity was observed in the case of green chilli and spinach (Table 2). These results are in accordance with those reported by Müftuigil (1985). He observed that peroxidase activity was found in all the samples of fresh vegetables investigated. According to Müftügil cabbage and green beans had high enzyme activities.

Table 2. Evaluation of peroxidase activity in selected vegetables.

\begin{tabular}{llllll}
\hline \multirow{2}{*}{ Vegetable } & \multicolumn{1}{l}{ Time (min) } & $\mathbf{2}$ & $\mathbf{3}$ & $\mathbf{4}$ & $\mathbf{5}$ \\
\cline { 2 - 6 } & $\mathbf{1}$ & $0.91 \pm 0.06$ & $1.2 \pm 0.09$ & $1.53 \pm 0.07$ & $1.7 \pm 0.06$ \\
\hline Cabbage & $0.5 \pm 0.03$ & $0.32 \pm 0.11$ & $0.48 \pm 0.15$ & $0.63 \pm 0.17$ & $0.76 \pm 0.21$ \\
Cauliflower & $0.17 \pm 0.04$ & $0.17 \pm 0.01$ & $0.19 \pm 0.01$ & $0.20 \pm 0.01$ & $0.22 \pm 0.02$ \\
Carrot & $0.15 \pm 0.01$ & $0.13 \pm 0.02$ & $0.14 \pm 0.02$ & $0.15 \pm 0.01$ & $0.17 \pm 0.01$ \\
Green chilli & $0.11 \pm 0.02$ & $0.13 \pm 0.01$ & $0.14 \pm 0.01$ & $0.15 \pm 0.01$ & $0.17 \pm 0.01$ \\
Spinach & $0.11 \pm 0.02$ & & & & \\
\hline
\end{tabular}

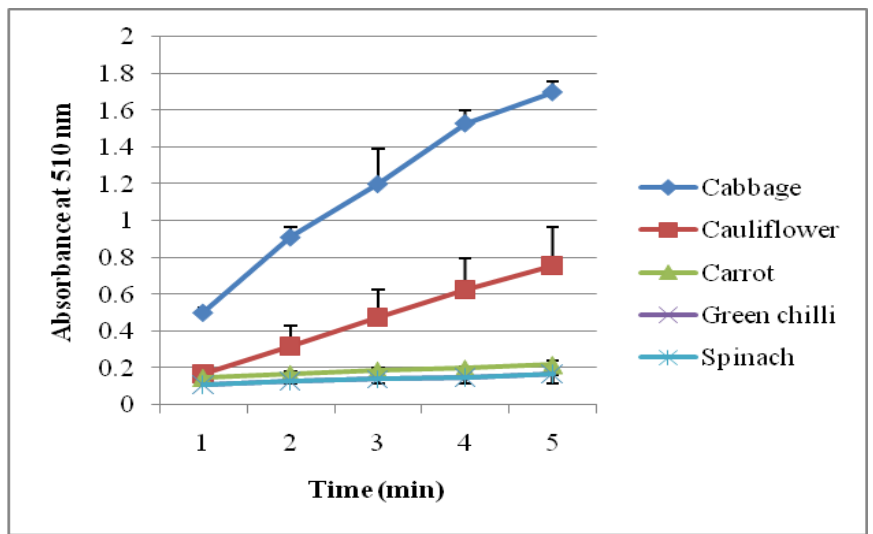

Fig. 2: Evaluation of peroxidase activity in selected vegetables.

Peroxidase activity in terms of moles/min (Table 3 and Fig. 3) in different vegetables samples were: cabbage $(3.55 \pm 0.18)>$ cauliflower $(1.43 \pm 0.41)>$ carrot $(0.57$ $\pm 0.04)>$ green chilli $(0.53 \pm 0.08)>$ spinach $(0.43 \pm$ $0.04)$ respectively.

Table 3. Peroxidase activity in selected vegetables (moles/min).

\begin{tabular}{ll}
\hline Vegetable & Mean \pm SD \\
\hline Cabbage & $3.55 \pm 0.18$ \\
Cauliflower & $1.43 \pm 0.41$ \\
Carrot & $0.57 \pm 0.04$ \\
Green chilli & $0.53 \pm 0.08$ \\
Spinach & $0.43 \pm 0.04$ \\
\hline
\end{tabular}

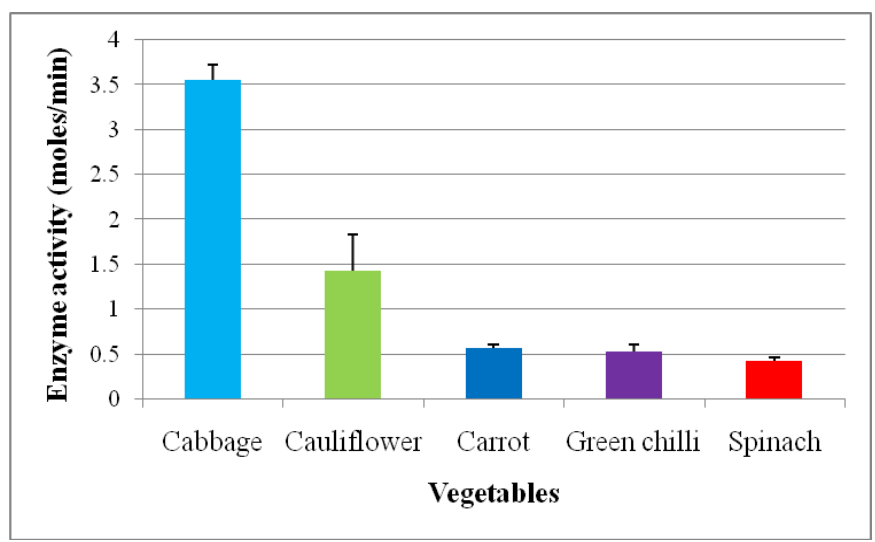

Fig. 3: Peroxidase activity in selected vegetables (moles/min).

\section{Conclusion}

All the vegetable samples investigated exhibited peroxidase activity. Peroxidase activity among the different vegetables varied significantly. Highest peroxidase activity was observed in the case of cabbage while lowest peroxidase activity was observed in the case of green chilli and spinach.

\section{Conflict of interest statement}

Authors declare that they have no conflict of interest.

\section{Acknowledgement}

Authors are thankful to Management and Principal 
Prof. Y. Ashok, Bhavan's Vivekananda College, Secunderabad, for providing necessary facilities and constant encouragement.

\section{References}

Adams, J. B., 1997. Regeneration and the kinetics of peroxidase inactivation. Food Chem. 60, 201-206.

Agner, K., 1943. Verdoperoxidase. Adv. Enzymol. 3, 137-148.

Agostini, E., Hernandez-Ruiz, J., Arnao, M. B., Milrand, S. R., Tigier, H. A., Acosta, M., 2002. A peroxidase isoenzyme secreted by turnip (Brassica napus) hairy-root culture inactivation by hydrogen peroxide and application in diagnostic kits. Biotechnol. Appl. Biochem. 35, 1-7.

Akhtar, S., Khan, A. A., Husain, Q., 2005. Partially purified bitter gourd (Momordica charantia) peroxidase catalyzed decolorization of textile and other industrially important dyes. Bioresour. Technol. 96, 1804-1811.

Ambreen, S., Rehman, K., Zia, M. A., Habib, F., 2000. Kinetic studies and partial purification of peroxidase in soybean. Pak. J. Agric. Sci. 37(3-4), 119-122.

Azevedo, A. M., Martins, V. C., Prazeres, D. M., Vojinovic, V., Cabral, J. M., Fonseca, L. P., 2003. Horseradish peroxidase: A valuable tool in biotechnology. Biotechnol. Annu. Rev. 9, 199-247.

Barnes, C.S., Upadrashta, B., Pacheco, F., Porton, J., 1993. Enhanced sensitivity of immunoblouing with POD conjugated antibodies using an adsorbed substrate method. J. Chem. 61(2), 281-288.

Bhunia, A., Duran, S., Wangikar, P. P., 2001. Horseradish peroxidase catalyzed degradation of industrially important dyes. Biotechnol. Bioeng. 72, 562-567.

Brill, A.S., 1996. Peroxidase and Catalase Comprehensive Biochemistry. Vol. XIV, Elsevier Pub. Co. Amsterdam. pp.447-479.

Bruemmer, J. H., Roe, B., Bowen, E. R., 1976. Peroxidase reactions and orange juice quality. J. Food Sci. 41, 186.

Clemente, E., 2002. Peroxidase from oranges [(Citrus sinenses (L.) Osbeck]. Eur. Food Res. Technol. 215, 164-168.

Duran, N., Esposito, E., 2000. Potential applications of oxidative enzymes and phenoloxidase-like compounds in wastewater and soil treatment: a review. Appl. Catal. B: Environ. 28, 83-99.

Gorin, N., Heidema, F. T., 1976. Peroxides activity in Golden Delicious apples as a possible parameter of ripening and senescence. J . Agric. Food Chem. 24, 200-201.

Haard, N. F., 1977. Physiological roles of peroxidase in post-harvest fruit and vegetables. In: Enzymes in Food and Beverages Processing (Eds.: Ory, R. L., St. Angelo, A. J.). ACS. 143p.

Harris, D.L., Loew, G.H., 1996. Identification of putative peroxide intermediates of peroxidase by electronic structure and spectra calculations. J. Chem. Sci. 118, 10588-10594.

Jen, J. J., Seo, A., Flurkey, W.H., 1980. Tomato peroxidase: purification via hydrophobic chromatography. J. Food Sci. 45, 60-63.

Kampis, A., Bartuczkovacs, O., Hoschke, A., Aosvigyazo, V., 1984. Changes in peroxidases activity of broccoli during processing and frozen storage. Lebensm. Wiss. Technol. 17, 293-295.

Kwak, S., Kim, S., Lee, K.H., Jung, I.H., Jin, J.R., 1995. Acidic peroxidases from suspension culture of sweat potato. Phytochem. 39(5), 981-984.

Llano, K. M., Haedo, A. S., Gerschenson, L. N., Rojas, A. M., 2003. Mechanical and biochemical response of kiwifruit tissue to steam blanching. Food Res. Int. 36(8), 767-775.

Miesle, T. J., Proctor, A., Lagrimini, L. M., 1991. Peroxidase activity isoenzymes, and tissues localization in developing high bush bluberry fruit. J. Amer. Soc. Hortic. Sci. 116, 827-830.

Müftuigil, N., 1985. The peroxidases enzyme activity of some vegetables and its resistance to heat. J. Sci Food Agric. 36, 877-880.

Nebesky, E. A., Esselen, W. B. Jr., Kaplan, A. M., Fellers, C. R., 1950. Thermal destruction and stability of peroxidase in acid foods. Food Res. 15, 114.

Neves, V. A., 2002. Ionically bound peroxidase from peach fruit. Braz. Arch. Biol. Technol. 45, 7-16.

Onsa, G. H., Saari, N., Selamat, J., Bakar, J., 2004. Purification and characterization of membranebound peroxidases from Metroxylon sagu. Food Chem. 85, 365-376.

Porstmann, B., 1981. Comparison of chromogens for the determination of horseradish peroxidase as a marker in enzyme immunoassay. J. Clin. Chem. Clin. Biochem. 19, 435-439.

Reed, G., 1975. Oxidoreductase: Enzymes in Food Processing. Academic Press, USA. 216p.

Regalado, C., Garcia-Almendárez, B. E., DuarteVázquez, M. A., 2004. Biotechnological applications of peroxidases. Phytochem. Rev. 3, 243-256. 
Rehman, K., Yaqub, M., Sheikh, M. A., Arshad, M., 1999. Extraction and evaluation of peroxidases from various vegetable sources. Int. J. Agric. Biol. 1(3), 170-173.

Rhotan, C., Nicholas, J., 1989. Changes in acidic and basic peroxidase activity during tomato fruit ripening. Hortic. Sci. 24, 340-342.

Robinson, D. S., 1987. Scavenging enzyme and catalases. In: Biochemistry and Nutritional Value (Ed.: Robinson, D. S.). Longman Scientific and Technical, Harlow, U.K. pp.459-465.

Sarika, D., Ashwin Kumar, P.S.S., Shaik Arshad, Sukumaran, M.K., 2015. Purification and evaluation of horseradish peroxidase activity. Int. J. Curr. Microbiol. Appl. Sci. 4(7), 367-375.
Shaffiqu, T. S., Roy, J. J., Nair, R. A., Abraham, T. E., 2002. Degradation of textile dyes mediated by plant peroxidases. Appl. Biochem. Biotechnol. 102-103, 315-326.

Singh, J., Dubey, A., Diwakar, S. K., Rawat, S. K., Batra, N., Josh, A., 2010. Biochemical characterization of peroxidases from the fruits of Mallus pumilus. Int. Res. J. Biotechol. 1(14), 50-58.

Trinder, P., Webster, D., 1984. Determination of HDLcholesterol using 2,4,6-tribromo-3-hydroxybenzoic acid with a commercial CHOD-PAP reagent. Ann. Clin. Biochem. 21, 430-433.

Zia, M.A., Rehman, K., Saeed, M.K., Ahmed, A., Ghaffar, A., 2001. Partial purification of peroxidase from tomato. Science. 1(6), 404-406.

\section{How to cite this article:}

Jha, P. K., Ganesh Sandeep, B.V.S.R.K.P., Raju, K., Sukumaran, M. K., 2017. Evaluation of peroxidase activity in selected vegetables from Hyderabad, Telangana, India. Int. J. Curr. Res. Biosci. Plant Biol. 4(8), 106-110. doi: https://doi.org/10.20546/ijcrbp.2017.408.014 